\title{
Application of Treffinger Learning Model Combined With Audio Visual Media To Improve Basic Chemistry Learning Outcomes STKIP PI Makassar Students
}

\author{
Haris Munandar ${ }^{\mathrm{a},}$, Muhammad Fath Azzajjd ${ }^{\mathrm{b}}$ \& Dewi Satria Ahmar \\ ${ }^{a}$ Universitas Negeri Gorontalo, Indonesia \\ ${ }^{b}$ Universitas Sembilanbelas November Kolaka, Indonesia \\ ${ }^{c}$ Universitas Tadulako, Indonesia
}

\begin{abstract}
The research is Classroom Action Research, which aims to improve basic chemistry student learning outcomes with the application of Treffinger's learning model with the help of audio visual media on colloidal system materials. Data collection techniques can be done with an observation sheet of student learning activities and evaluation at the end of each cycle. The collected data is analyzed using descriptive statistical analysis. The results showed that the application of Active Knowledge Sharing strategy with Buzz Group method can improve basic chemistry learning outcomes in STKIP PI Makassar students which is characterized by an increase in the average learning outcome of cycle I students by 63.33 and cycle II by 72.67 and an increase in the completion of learning outcomes in cycle I which is 9 people or $22.5 \%$ and cycle II 35 people or $87.5 \%$.
\end{abstract}

Keywords: learning outcomes; treffinger learning; media audio visual

\section{Introduction}

Salah satu masalah yang dihadapi dalam dunia pendidikan kita adalah kurang efektifnya proses pembelajaran. Pembelajaran yang efektif adalah pembelajaran yang mampu mengarahkan peserta didik mengembangkan potensi dirinya, bukan sekedar mampu membuat peserta didik menghafalkan fakta dan konsep terkait materi pelajarannya. Kimia merupakan salah satu bagian ilmu pengetahuan yang mengkaji materi yang bersifat mikro yang juga dikembangkan berdasarkan eksperimen. Karakteristik inilah yang terkadang membuat peserta didik kesulitan untuk menggambarkan obyek kimia yang dipelajari. Untuk menyiasati problematika ini diperlukan sebuah model pembelajaran yang mampu membantu peserta didik untuk bisa meningkatkan kualitas pembelajaran kimia sesuai dengan perkembangan IPTEK

Dalam Undang-Undang No. 20 Tahun 2003 Tentang Sistem Pendidikan Nasional pasal 1 ayat 20 menjelaskan bahwa pembelajaran merupakan proses interaksi peserta didik dengan pendidik dan sumber belajar pada suatu lingkungan belajar. Jika dikaji lebih spesifik, dapat dilihat Pembelajaran kimia yang dilaksanakan hendaknya bukan hanya sekedar menyajikan fakta, prinsip, dak konsep, akan tetapi juga menekankan pada pengalaman riil yang dapat diberikan melalui penggunaan dan pengembangan keterampilan proses dan sikap ilmiah.

\footnotetext{
* Corresponding author.

E-mail address: harismunandar@ung.ac.id (Haris Munandar)
} 
Pembelajaran menurut Corey (Sagala, 2011) adalah suatu proses yang memungkinkan lingkungan peserta didik secara disengaja dikelola untuk membuat peserta didik turut serta dalam tingkah laku tertentu dalam kondisi-kondisi khusus atau menghasilkan respons terhadap situasi tertentu.

Proses pembelajaran yang didesain hendaknya selalu berpusat pada peserta didik. Hal ini penting, karena akan semakin memudahkan peserta didik dalam mengembangkan aspek kognitif, afektif, dan psikomotoriknya (Sanjaya, 2012). Selain menyusun model pembelajaran yang efektif, diperlukan pula sebuah media pembelajaran yang mampu memberikan kemudahan pengalaman pada peserta didik untuk mendorong motivasi belajar, memperjelas dan mempermudah konsep yang kompleks menjadi lebih sederhana, kongkret, dan mudah dipahami. Model Pembelajaran dapat diartikan sebagai suatu perencanaan atau suatu pola yang digunakan sebagai pedoman dalam merencanakan pembelajaran di kelas. Model pembelajaran mengacu pada pendekatan pembelajaran yang digunakan, termasuk di dalamnya tujuan-tujuan pengajaran, tahap-tahap kegiatan pembelajaran, lingkungan pembelajaran dan pengelolaan kelas (Trianto, 2011). Pemilihan model pembelajaran yang tepat dapat memberikan kemudahan bagi peserta didik untuk memahami pelajaran sehingga memungkinkan mereka untuk mendapatkan hasil belajar yang lebih baik dan efektif.

Media pembelajaran alat bantu dalam pembelajaran yang bertujuan (a) mempermudah proses pembelajaran di kelas; (b) meningkatkan efisiensi proses pembelajaran; (c) menjaga relevansi antara materi pelajaran dengan tujuan belajar, dan; (d) Membantu konsentrasi pembelajar dalam proses pembelajaran. Media pembelajaran dapat pula diartikan sebagai media yang membawa pesan-pesan atau informasi yang bertujuan instruksional atau mengandung maksudmaksud pengajaran (Hamdani, 2012).

Berdasarkan observasi awal yang dilakukan di STKIP Pembangunan Indonesia (PI) Makassar, mahasiswa cenderung terlihat pasif dalam pembelajaran kimia dasar. Hal ini ditunjukkan dengan kurangnya mahasiswa yang berpartisipasi untuk bertanya atau menjawab pertanyaan. Hal ini menunjukkan kurangnya rasa percaya diri mahasiswa dalam proses pembelajaran, sehingga dibutuhkan suatu model pembelajaran dapat memberikan kemudahan bagi peserta didik untuk memahami pelajaran sehingga memungkinkan mereka untuk mendapatkan hasil belajar yang lebih baik dan efektif.

Salah satu model pembelajaran yang dapat meningkatkan hasil belajar peserta didik yaitu pembelajaran Treffinger dipadu dengan Media Audio Visual. Model pembelajaran ini termasuk dalam pembelajaran kooperatif yang memungkinkan keterlibatan peserta didik dalam pembelajaran sehingga diharapkan bisa meningkatkan hasil belajarnya. Model Treffinger dikenalkan oleh Donald J. Treffinger pada tahun 1980. Donald J. Treffinger adalah presiden di Center of Creative Learning, Inc Sarasota, Florida. Menurut Treffinger (dalam Huda 2013), digagasnya model ini adalah karena perkembangan yang terus berubah dengan cepat dan semakin kompleksnya permasalahan yang harus dihadapi. Oleh karena itu, untuk mengatasi permasalahan tersebut, diperlukan suatu cara agar dapat menyelesaikan suatu permasalahan dengan kritis dan kreatif sehingga menghasilkan solusi yang paling tepat.

Menurut Shoimin (2014) mengemukakan bahwa model treffinger merupakan salah satu model pembelajaran yang menitikberatkan pada kreativitas peserta didik. Dengan melibatkan keterampilan kognitif dan afektif pada setiap tingkat dari model ini, treffinger menunjukkan saling berhubungan dan ketergantungan antara keduanya dalam mendorong belajar kreatif. Salah satu karakteristik dari model treffinger sesuai untuk digunakan dalam pembelajaran agar siswa terlibat aktif dalam proses pembelajaran. Kegiatan pembelajaran yang dilakukan pun akan berpusat pada siswa. Peran guru sebagai fasilitator yang mengarahkan siswa untuk belajar dan mencapai suatu kompetensi.

Berdasarkan penelitian yang dilakukan (Sari \& Putra, 2015) menunjukkan bahwa model pembelajaran Treffinger berpengaruh signifikan terhadap kemam- puan berpikir kritis mahasiswa dan model pembelajaran Treffinger berpengaruh signifikan terhadap kemampuan berpikir kreatif mahasiswa.Sedangkan berdasarkan penelitian yang dilakukan oleh (Larasati, 2020) menunjukkan bahwa pengaplikasian model pembelajaran Treffinger memberikan pengaruh positif terhadap kemampuan berpikir kreatif mahasiswa PGSD UWKS. Hal ini dibuktikan dengan hasil perhitungan analisis uji $\mathrm{t}$ mengunakan independen sample t test diperoleh data $\mathrm{p}$-level lebih kecil dari $0,05(\mathrm{p}<0,05)$ 
yaitu 0,00. Rata-rata skor pretest lebih rendah dari skor post test di kelas eksperimen. Hal tersebut disebabkan oleh langkah-langkah model pembelajaran Treffinger yang di dalamnya terdapat tahapan-tahapan belajar kreatif dari yang sederhana sampai yang kompleks. Selain temuan utama penelitian ditemukan juga kelebihan dan kelemahan penelitian dengan menggunakan model ini.

Adapun Media audio visual adalah media yang melibatkan indera pendengaran dan penglihatan sekaligus dalam satu proses. Sifat pesan yang dapat disalurkan melalui media audio visual adalah pesan verbal dan non verbal yang terlihat layaknya media visual dan terdengar layaknya media audio. Menurut Arsyad (2011), secara khusus pengertian media dalam proses belajar mengajar cenderung diartikan sebagai alat-alat grafis, photografis, atau elektronis untuk menangkap, memproses, dan menyusun kembali informasi visual atau verbal. Pada mulanya media hanya berfungsi sebagai alat bantu visual dalam belajar/mengajar, yaitu berupa sarana yang dapat memberikan pengalaman visual kepada peserta didik antara lain untuk mendorong motivasi belajar, memperjelas konsep yang abstrak, dan mempertinggi daya serap atau retensi belajar. Kemudian Miarso dalam bukunya mengatakan dengan masuknya pengaruh teknologi audio pada sekitar pertengahan abad ke-20 lahirlah peraga audio visual yang terutama menekankan penggunaan pengalaman yang konkrit untuk menghindarkan verbalisme (Febliza \& Afdal, 2015).

Berdasarkan penelitian yang dilakukan oleh (Sayidiman, 2012) menunjukkan bahwa Penggunaan media audio visual secara sistematis dengan langkah-langkah yang telah disusun dengan berbagai persiapan dapat meningkatkan kemampuan dan minat mahasiswa terhadap mata kuliah studio seni tari. Sedangkan menurut hasil penelitian dari (Huda et al., 2020) menunjukkan bahwa bahwa Treffinger berbantuan media audio visual berupa video interaktifdapat menghasilkan kemampuan berpikir kritis matematis peserta didik yang lebih baik dibandingkan pembelajaran Konvensional berbantuan video interaktif. Oleh karena itu pembelajaran ini dapat dijadikan alternatif bagi guru dalam pembelajaran di kelas atau saat daring, sehingga dapat menghasilkan kemampuan berpikir kritis matematis yang lebih baik lagi.

Tujuan dari model pembelajaran treffinger adalah membantu peserta didik dalam menyelesaikan masalah-masalah yang mereka temui dalam pembelajaran melalui pemahaman konsep. Pembelajaran ini akan membantu mahasiswa dalam mengembangkan kemampuan siswa untuk mendefinisikan masalah, mengumpulkan data, menganalisis data, membangun hipotesis dan percobaan untuk memecahkan suatu permasalahan. Sedangkan media audio visual dalam pembelajaran adalah media yang dapat menjadi perantara bagi peserta didik dalam pembelajaran melalui penglihatan dan pendengaran sehingga diharapkan bisa semakin memudahkan peserta didik dalam membangun pengetahuan, sikap, dan keterampilannya.

Melalui uraian latar belakang diatas, maka penulis bermaksud untuk meneliti Penerapan Model Pembelajaran Treffinger Dipadu Media Audio Visual Untuk Meningkatkan Hasil Belajar Kimia Dasar Mahasiswa STKIP PI Makassar.

\section{Methods}

Penelitian ini merupakan penelitian tindakan kelas (PTK) atau classroom action research yang meliputi: perencanaan, pelaksanaan tindakan, observasi, dan refleksi yang berulang. Penelitian ini dilaksanakan selama dua bulan dari bulan Juli-Agustus 2019. Lokasi penelitian ini dilaksanakan di kampus STKIP PI Makassar semester ganjil Tahun Akademik 2019/2020. Penelitian ini dilaksanakan di kelas I B Program Studi pendidikan biologi STKIP PI Makassar semester ganjil tahun ajaran 2018/2019 dengan jumlah siswa 40 orang mahasiswa terdiri dari 16 laki-laki dan 24 mahasiswa perempuan.

Prosedur kerja dalam penelitian ini dilaksanakan sesuai dengan rancangan penelitian tindakan kelas yang bersiklus dengan tahapan-tahapan terdiri dari beberapa tahapan, yakni : Perencanaan (planning); Tindakan (acting); Observasi (observing); Refleksi (reflecting). Banyaknya siklus yang dilakukan tergantung pada peningkatan hasil belajar. Setiap siklus terdiri dari empat kali pertemuan (tiga kali tatap muka dan satu kali evaluasi). Teknik pengumpulan data dalam penelitian terdiri dari tes hasil belajar dan lembar obesrvasi aktivitas mahasiswa. Tes hasil belajar terbagi atas dua yaitu pre-tes dan dan post-tes. Sebelum melaksanakan proses pembelajaran, diberikan tes awal untuk 
mengidentifikasi tingkat kesulitan materi dan menyamakan persepsi awal terkait rencana pembelajaran. Setelah pembelajaran selesai, guru memberikan lagi tes akhir, untuk mengetahui daya serap siswa terhadap materi yang telah diajarkan. Teknik ini digunakan untuk memperoleh data mengenai peningkatan hasil belajar mahasiswa dalam proses pembelajaran dengan menggunakan model pembelajaran treffinger dipadu media audio visual dengan menggunakan lembar observasi aktivitas mahasiswa.

Data hasil belajar mahasiswa dianalisis kemudian nilai yang diperoleh dikategorikan menjadi beberapa kategori yakni: sangat tinggi, tinggi, sedang, rendah, dan sangat rendah. Data prestasi yang diperoleh dikategorikan berdasarkan tehnik kategori standar yang ditetapkan.Teknik analisis data penelitian ini terdiri dari dua bagian yaitu analisis data deskriptif dan analisis data inferensi. Menurut Sugiyono (2011) analisis data deskriptif ini digunakan untuk mendeskripsikan atau menggambarkan data yang telah didapatkan, sedangkan analisis data inferensial digunakan untuk menguji hipotesis penelitian.

Tabel 1. Kategori Hasil Belajar Siswa

\begin{tabular}{cc}
\hline Skor & Kategori \\
\hline $0-34$ & Sangat Rendah \\
$35-54$ & Rendah \\
$55-69$ & Sedang \\
$70-84$ & Tinggi \\
$85-100$ & Sangat Tinggi \\
\hline
\end{tabular}

Untuk memperoleh presentase skor hasil belajar siswa, digunakan teknik analisis data yaitu dengan rumus sebagai berikut:

$P=\frac{\mathrm{F}}{\mathrm{N}} \times 100 \%$

Keterangan:

$\mathrm{P}=$ Persentase

$\mathrm{F}=$ Frekuensi aktifitas siswa

$\mathrm{N}=$ Banyaknya individu

\section{Result and Discussion}

3.1 Hasil Observasi Aktivitas Belajar Mahasiswa

Tabel 2. Distribusi dan Frekuensi Aktivitas Belajar Mahasiswa Siklus I

\begin{tabular}{lcccccc}
\hline \multirow{2}{*}{\multicolumn{1}{c}{ Aktivitas siswa }} & \multicolumn{3}{c}{ Pertemuan } & \multirow{2}{*}{ Jumlah } & \multirow{2}{*}{ Persentase } \\
\cline { 2 - 4 } & I & II & III & & & \\
\hline Menyimak penjelasan guru. & 16 & 17 & 20 & 53 & $44,16 \%$ \\
Menjawab pertanyan. & 12 & 13 & 15 & 40 & $33,33 \%$ \\
Mengemukakan pendapat. & 15 & 16 & 20 & 51 & $42,5 \%$ \\
Sikap menghargai dalam berdiskusi. & 18 & 20 & 25 & 63 & $52,5 \%$ \\
Ketertiban dalam mengikuti pembelajaran & 13 & 14 & 15 & 42 & $35 \%$ \\
Semangat dalam mengikuti pembelajaran & 24 & 27 & 30 & 81 & $67,5 \%$ \\
Keaktifan dalam mengerjakan soal. & 26 & 29 & 32 & 87 & $72,5 \%$ \\
& & & & & \\
\hline
\end{tabular}


Tabel 3. Distribusi dan Frekuensi Aktivitas Belajar Mahasiswa Siklus II

\begin{tabular}{lccccc}
\hline \multirow{2}{*}{\multicolumn{1}{c}{ Aktivitas siswa }} & \multicolumn{3}{c}{ Pertemuan } & \multirow{2}{*}{ Jumlah } & \multirow{2}{*}{ Persentase } \\
\cline { 2 - 4 } & I & II & III & & \\
\hline Menyimak penjelasan guru. & 26 & 17 & 38 & 91 & $75,83 \%$ \\
Menjawab pertanyan. & 18 & 19 & 35 & 72 & $60 \%$ \\
Mengemukakan pendapat. & 16 & 28 & 37 & 91 & $75,83 \%$ \\
Sikap menghargai dalam berdiskusi. & 28 & 30 & 38 & 96 & $80 \%$ \\
Ketertiban dalam mengikuti pembelajaran & 19 & 22 & 38 & 79 & $65,83 \%$ \\
Semangat dalam mengikuti pembelajaran & 28 & 31 & 36 & 95 & $79,16 \%$ \\
Keaktifan dalam mengerjakan soal. & 29 & 33 & 37 & 99 & $82,5 \%$ \\
& & & & & \\
& & & &
\end{tabular}

Dari hasil refleksi pada siklus I dapat dilihat beberapa poin dalam penelitian ini, diantaranya: (1) Ketuntasan hasil belajar mahasiswa pada materi kimia dasar masih rendah, (2) kurangnya pemahaman dan kerja sama mahasiswa dalam mengerjakan soal tentang kimia dasar yang telah diberikan; (3) Kurangnya partisipasi aktif bertanya dan menjawab pertanyaan selama pembelajaran berlangsung. Dari beberapa poin ini terlihat kekurangan-kekurangan siklus I yang perlu diperbaiki pada siklus II.

Adapun rincian aktivitas peserta didik pada siklus I dan siklus II yakni aktivitas siswa dalam menyimak penjelasan guru pada siklus I mencapai $44,16 \%$ dan pada siklus II naik menjadi 75,83 \%. Aktivitas mahasiswa dalam menjawab pertanyaan pada siklus I mencapai 33,33 \% dan pada siklus II naik menjadi $60 \%$. Aktivitas mahasiswa dalam mengemukakan pendapat pada saat proses pembelajaran pada siklus I mencapai $42,5 \%$ dan pada siklus II naik menjadi $75,83 \%$. Sikap mengharagai dalam berdiskusi pada saat proses pembelajaran pada siklus I mencapai 52,5\% dan pada siklus II naik menjadi $80 \%$. Ketertiban siswa dalam mengikuti pembelajaran biologi pada siklus I mencapai $35 \%$ dan pada siklus II naik menjadi $65,83 \%$. Semangat siswa dalam mengikuti pembelajaran kimia dasar setelah diterapkan model pembelajaran treffinger dipadu media audio visual pada siklus I mencapai 67,5\% dan pada siklus II naik menjadi $79,16 \%$. Keaktifan siswa dalam mengerjakan soal pada siklus I mencapai 72,5 dan pada siklus II naik menjadi 82,5 . Rata-rata aktivitas belajar pada siklus I 49,52\% dan pada siklus II menjadi 76,85\% dengan peningkatan sebesar $27,33 \%$.

\subsection{Hasil Belajar Mahasiswa Siklus I dan Siklus II}

Tabel 4. Deskripsi hasil belajar mahasiswa siklus I dan siklus II

\begin{tabular}{ccc}
\hline & \multicolumn{2}{c}{ Nilai Statistik } \\
\cline { 2 - 3 } Aspek & Siklus I & Siklus II \\
\hline Jumlah Siswa & 40 & 40 \\
Nilai ideal & 100 & 100 \\
Tertinggi & 80 & 90 \\
Terendah & 50 & 55 \\
Median & 60 & 76 \\
Modus & 50 & 75 \\
Rata-rata & 63,33 & 72,67 \\
\hline
\end{tabular}

Adapun keseluruhan nilai yang diperoleh mahasiswa, jika dikelompokkan dalam tabel pengkategorian hasil belajar mahasiswa yang diajar melalui pembelajaran treffinger dipadu media audio visual dapat dilihat pada tabel berikut: 
Tabel 5. Kategori hasil belajar mahasiswa siklus I dan siklus II

\begin{tabular}{cccccc}
\hline & & \multicolumn{2}{c}{ Siklus I } & \multicolumn{2}{c}{ Siklus II } \\
\cline { 3 - 6 } & Kategori & $\mathbf{F}$ & $\mathbf{( \% )}$ & $\mathbf{F}$ & $\mathbf{( \% )}$ \\
\hline $0-34$ & Sangat Rendah & 0 & $0 \% \%$ & 0 & $0 \%$ \\
$35-54$ & Rendah & 13 & $32,5 \%$ & 1 & $2,5 \%$ \\
$55-69$ & Sedang & 12 & $30 \%$ & 2 & $5 \%$ \\
$70-84$ & Tinggi & 13 & $32,5 \%$ & 18 & $45 \%$ \\
$85-100$ & Sangat Tinggi & 2 & $5 \%$ & 19 & $47,5 \%$ \\
\hline & Jumlah & 40 & 100 & 40 & 100 \\
\hline
\end{tabular}

Berdasarkan hasil penelitian dari dua siklus, terlihat bahwa siklus II ini menunjukkan peningkatan dari siklus I. Dalam hal peningkatan hasil belajar kimia dasar dengan penerapan model pembelajaran treffinger dipadu media audio visual, membuat mahasiswa lebih aktif dalam pembelajaran. Hal ini terlihat dari aktivitas mahasiswa dalam mengkonstruksi pengetahuannya secara bersama-sama, semakin aktif dalam bekerja sama dan adanya alat bantu dalam pembelajaran yang semakin memudahkan mahasiswa dalam mendapatkan hasil belajar yang lebih baik. Melalui penerapan model pembelajaran treffinger dipadu media audio visual, melatih mahasiswa untuk menyusun tahapan-tahapan belajarnya menjadi lebih kreatif dan merealisasikan gagasan pembelajarannya menjadi tindakan yang konkret.Keberhasilan dari pembelajaran pada siklus II ini terlihat pada kenaikan yang signifikan hasil belajar kimia dasar mahasiswa pada kategori tinggi dan sangat tinggi

Berdasarkan hasil penelitian dan analisis data mengenai perbandingan nilai statistik, perbandingan kategori hasil belajar dan perbandingan tingkat ketuntasan kedua siklus menunjukkan adanya peningkatan aktivitas dan hasil belajar mahasiswa dari siklus I ke siklus II.

\section{Conclusion}

Berdasarkan hasil penelitian yang sudah diuraikan diatas maka dapat disimpulkan bahwa penerapan model pembelajaran Treffinger dengan bantuan media Audio Visual, dapat meningkatkan hasil belajar kimia dasar mahasiswa STKIP PI Makassar yang ditandai dengan adanya peningkatan rata-rata hasil belajar mahasiswa dari siklus I sebesar 63,33 dan menjadi 72,67 pada siklus II. Selain itu, terlihat adanya peningkatan yang signifikan ketuntasan hasil belajar pada siklus I yaitu 9 orang atau $22,5 \%$ dan pada siklus II menjadi 35 orang atau 87,5\%.

\section{Acknowledgements}

Terimakasih penulis ucapkan kepada STKIP Pembangunan Indonesia Makassar atas segala bantuan dan kesempatan yang telah diberikan kepada penulis untuk dapat melaksanakan penelitian ini.

\section{References}

Sudijono, A. (2012). Pengantar Evaluasi Pendidikan. Jakarta: PT. Raja Grafindo Persada.

Aris, S. 2014. 68 Model Pembelajaran Inovatif Dalam Kurikulum 2013. Yogyakarta: Ar-Ruzz Media.

Arsyad, A. 2014. Media Pembelajaran. Jakarta: PT Raja Grafindo Persada

Febliza, A. \& Afdal, Z. 2015. Statistic Dasar Penelitian Pendidikan. Pekanbaru: Adefa Grafika. 
Hamdani. 2011. Strategi Belajar Mengajar. Bandung: Pustaka Setia.

Huda, M. 2013. Model-Model Pengajaran dan Pembelajaran (Isu-Isu Metodis dan Paradigmatis). Yogyakarta: Pustaka Pelajar.

Huda, L. L., Masykur, R., \& Andriani, S. (2020). Analisis Kemampuan Berpikir Kritis Matematis: Dampak Pembelajaran Treffinger. Jurnal MAJU, 8(1), 8-18.

Larasati, D. A. (2020). Pengaruh Model Treffinger terhadap Keterampilan Berpikir Kreatif Mahasiswa Pendidikan Guru Sekolah Dasar. Musamus Journal of Primary Education, 2(2), 130-139. https://doi.org/10.35724/musjpe.v2i2.2331

Sagala, S. (2011). Konsep dan Makna Pembelajaran, Bandung: Alfabeta

Sanjaya, W. (2012). Strategi Pembelajaran Berorientasi Standar Proses Pendidikan. Jakarta: Kencana Prenada Media.

Sari, Y. I., \& Putra, D. F. (2015). Pengaruh Model Pembelajaran Treffinger terhadap Kemampuan Berpikir Kritis dan Kreatif Mahasiswa Universitas Kanjuruhan Malang. Jurnal Pendidikan Geografi, 20(2), 30-38. https://doi.org/10.17977/um017v20i22015p030 